\title{
WHITE PELICAN REPRODUCTION IN THE MOLLY ISLANDS BREEDING COLONY, YELLOWSTONE NATIONAL PARK
}

\author{
Kenneth L. Diem \\ Department of Zoology and Physiology \\ University of Wyoming
}

\section{Objectives}

Compared to other North American White Pelican, Pelecanus erythrorhynchos, breeding colonies, the Molly Islands Colony is a minor colony consisting of 400-600 adults (Lier and Behle, 1966; Diem and Condon, 1967; Sloan, 1973; Diem, 1976). Despite its small size, the colony is unique for these reasons: 1) it is the only White Pelican breeding colony in a national park; 2) the location of the colony at an elevation of $7,733 \mathrm{ft}(2,357 \mathrm{~m})$ is the highest recorded for any breeding colony of the species; 3) discovered in 1890, the colony has had variable surveillance since 1917, with relatively intense monitoring since 1965 ; 4) the breeding population is composed of birds from both coasts of North America; and 5) the colony's nesting sites on the two Molly Islands change frequently with no predictable pattern. The major objective of this project is to continue monitoring changes in the reproductive success of the Molly Islands White Pelican colony and to continue studies of the factors influencing those changes.

\section{Procedures}

Nesting and fledgling censuses continue to be taken from a boat 100-200 $\mathrm{ft}$ from shore. Because landing in the colony would be too much of a destructive disturbance, clutch data cannot be collected. Some errors in nest counting probably occur, however, the fledgling censuses are very accurate.

\section{Results}

Nesting and fledgling counts for the Molly Islands breeding water bird populations for the period 1977 through 1981 are presented in Table 1. The nesting efforts of the White Pelican are particularly notable since the 290 nests are the second largest total recorded for this colony. Schaller (1964) recorded 298 nests in 1962. Despite this auspicious start, the number of young White Pelicans fledged per nest was the lowest since 1976. The cold, late spring appears to have been largely responsible for the depressed reproductive effort of these early nesters.

By contrast, the Double-crested Cormorants, Phalacrocorax auritus, and

$$
-128-
$$




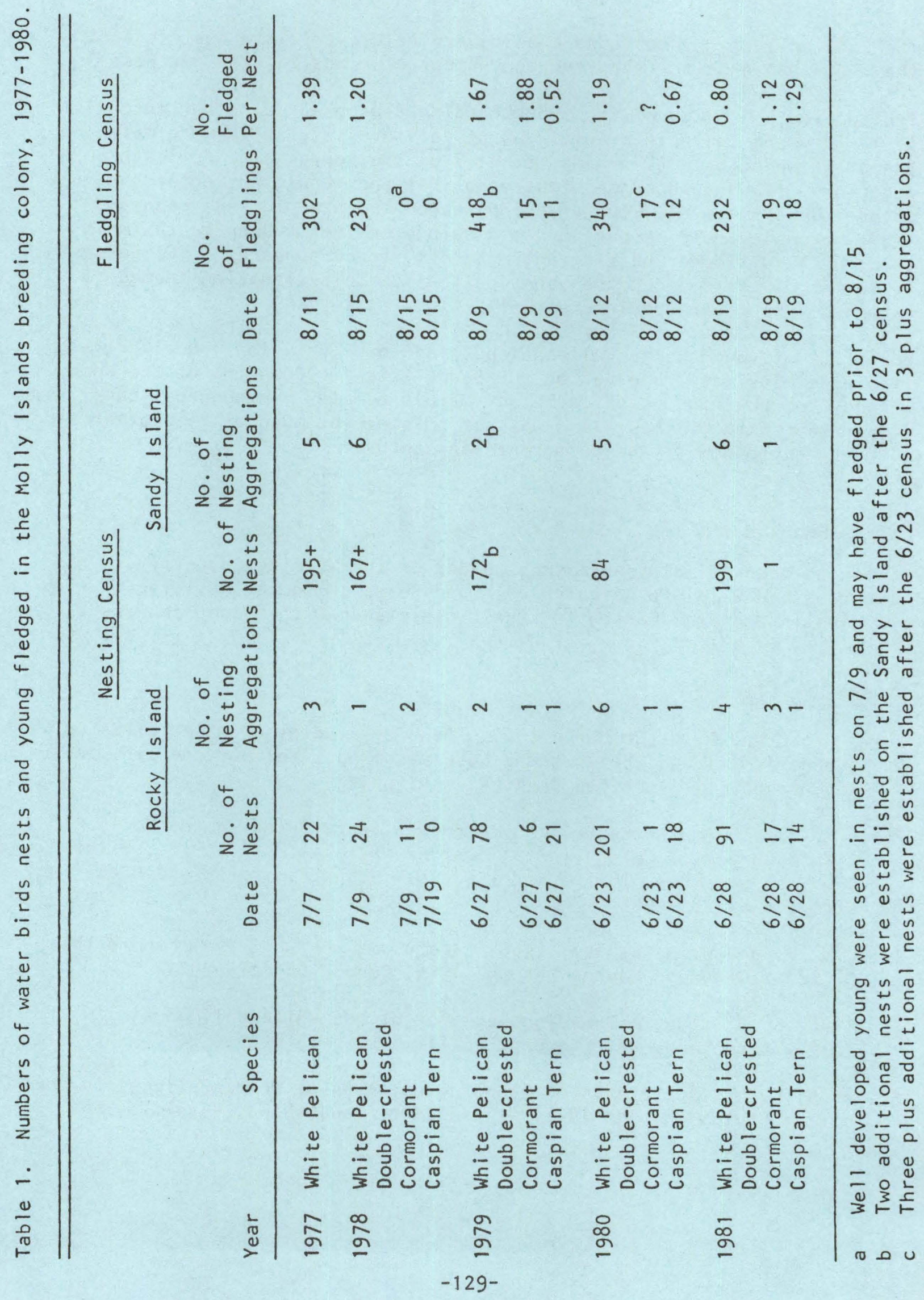


the Caspian Tern, Hydroprogne caspia, are relatively late nesters and they both had a better than average number of birds fledged per nest.

The delayed phenology of the 1981 breeding season was also reflected by $10-15$ young California Gulls, Larus californicus, which were only $3 / 4$ grown on August 19. In addition, 7 of the young White Pelicans were so poorly developed and feathered that they could not enter the water. Conservatively, the breeding season appeared to have been extended or delayed 10-14 days by cold, windy weather. Despite the existance of 10 different nesting aggregations, there appeared to be general uniformity of size among the young pelicans. This situation seemed to extend to the other species, as well.

Mortality of young White Pelicans appeared to be very low. No identifiable remains were observed on the Sandy Island. Scanning of the Rocky Island from the canoe, indicated no visible remains of young pelicans. Closer searching of the island was not possible because of the potential disturbance to non-flying cormorants and terns.

\section{Acknowledgements}

I wish to thank Stanley Anderson, Leader of the Wyoming Cooperative Fisheries and Wildlife Research Unit and Research Center Assistants John Austin and Jack Carson for their assistance with these censuses.

\section{Literature Cited}

Diem, K. L. and D. D. Condon. 1967. Banding studies of water birds on the Molly Islands, Yellowstone Lake, Wyoming. Yellowstone Lib. and Mus. Assoc., Yellowstone Park, WY. 41 pp.

Diem, K. L. 1979. White Pelican reproductive failures in the Molly Islands Breeding Colony in Yellowstone National Park. Proc. First Conf. on Sci. Res. in the Nat'l Parks. U.S.N.P. Trans. and Proc. Series. 5: 489-496.

Lier, M. F. and W. H. Behle. 1966. Status of the White Pelican in the United States and Canada through 1964, Condor 68: 279-292.

Schaller, G. B. 1964. Breeding behavior of the White Pelican at Yellowstone Lake, WY. Condor, 66(1): 3-23.

Sloan, N. F. 1973. Status of breeding colonies of White Pelicans in the United States through 1972. Inland Bird Band. News. 45(3): 83-96. 